\title{
PERIZINAN DI BIDANG PERBANKAN YANG BERIMPLIKASI TINDAK PIDANA
}

\author{
Nooritza Meidahnia \\ ichaitza@gmail.com \\ Pengamat Hukum
}

\begin{abstract}
In order to support the improvement of the implementation of development in Indonesia, banking institutions experienced fluctuating growth along with the progress and political developments in Indonesia, the development of the international economy also in line with increased demand banking services needs of the community will be strong and feasible. This is then gives a very strategic role in the development of the banking institutions in Indonesia because of the bank as a means to harmonize and balance of each element of the trilogy of development, economic growth and national stability, as defined in Article 4 of Law No. 10 of 1998 on Banking.
\end{abstract}

Keywords: license, banking, abuse.

\begin{abstract}
Abstrak
Sebagai upaya mendukung peningkatan pelaksanaan pembangunan di Indonesia, lembaga perbankan telah mengalami perkembangan yang fluktuatif seiring dengan kemajuan dan perkembangan politik di Indonesia dan perkembangan perekonomian internasional serta sejalan dengan peningkatan tuntutan kebutuhan masyarakat akan jasa perbankan yang tangguh dan sehat. Hal ini yang kemudian memberikan peranan yang sangat strategis kepada lembaga perbankan dalam pembangunan di Indonesia karena bank sebagai salah satu sarana dalam menyerasikan dan menyeimbangkan masing-masing unsur trilogi pembangunan, pertumbuhan ekonomi dan stabilitas nasional sebagaimana ditegaskan dalam Pasal 4 Undang Undang Nomor 10 tahun 1998 tentang Perbankan.
\end{abstract}

Kata kunci: perizinan, perbankan, penyalahgunaan. 


\section{Pendahuluan}

Indonesia sebagai negara yang sedang membangun untuk mengejar ketertinggalannya, khususnya pembangunan yang difokuskan pada sektor ekonomi, tengah menerapkan berbagai kemudahan dan penyederhanaan dalam pengaturan yang berkaitan dengan pembangunan tersebut guna mencapai tujuan yang dicita-citakan. Perubahan dan ketertiban atau keteraturan merupakan tujuan kembar dari masyarakat yang sedang membangun. Oleh karena itu, jika perubahan hendak dilakukan dengan teratur dan tertib, maka hukum merupakan sarana yang tidak dapat diabaikan dalam proses pembangunan. ${ }^{1}$

Dalam ruang lingkup pembangunan yang pada hakikatnya merupakan perubahan sosial berencana, pembangunan hukum telah menjadi kebutuhan yang tidak terelakkan sekalipun perencanaan di bidang ekonomi merupakan aspek yang menonjol, agar hasil-hasil pembangunan itu benar-benar dapat mencapai tujuan yang dicita-citakan, sebab hukum dapat dijadikan sandaran kerangka untuk mendukung usaha-usaha yang sedang dilakukan untuk membangun masyarakat, baik secara fisik maupun spiritual. ${ }^{2}$ Pembangunan di bidang hukum dimaksudkan untuk menjamin agar masyarakat dapat menikmati kepastian hukum dan perlindungan hukum yang berintikan keadilan dan kebenaran.

Richard Lange mengatakan ada dua problem pokok dalam pembaharuan hukum pidana. Pertama, keharusan untuk menyerasikan hukum pidana dengan ilmu empiris. Artinya, dalam pembaharuan hukum pidana harus memperhatikan kebutuhan masyarakat yang sesungguhnya. Kedua, hukum pidana harus diperbaharui sesuai tingkat kemajuan zaman. ${ }^{3}$ Keharusan untuk memperbaharui hukum pidana disebabkan oleh perkembangan kriminalitas yang berkaitan erat dengan perubahan dan perkembangan masyarakat Indonesia secara keseluruhan yang sedang mengalami proses modernisasi. ${ }^{4}$

Hukum perizinan merupakan bagian dari hukum administrasi yang berisi tindakan pemerintah berupa penetapan suatu keputusan yang digunakan oleh pemerintah sebagai sarana pengendalian terhadap tingkah laku warga. Terhadap hubungan tersebut, maka ketentuan yang berlaku dalam hukum administrasi juga berlaku dalam hukum perizinan, karena hukum perizinan merupakan bagian dari hukum administrasi.Membicarakan sistem perizinan selalu harus melihat pengertian izin sebagai suatu persetujuan dari pemerintah berdasarkan peraturan perundang-undangan untuk menyimpang dari ketentuan peraturan perundang-undangan tersebut. ${ }^{5}$ Dengan memberi izin pemerintah memperkenankan orang yang memohon untuk melakukan tindakan-tindakan tertentu yang sebenarnya dilarang, hal ini menyangkut perkenan bagi tindakan yang demi kepentingan umum mengharuskan pengawasan. Dengan demikian

\footnotetext{
1 Mochtar Kusumaatmadja, Masyarakat dan Pembinaan Hukum Nasional Suatu Uraian tentang Landasan Pikiran, Pola dan Mekanisme Pembaharuan Hukum di Indonesia, Bandung :Binacipta, 1976, h. 13.

2 Satjipto Rahardjo, Hukum, Masyarakat dan Pembangunan, Bandung : Alumni, 1980, h. 5.

3 Sudarto, "Suatu Pembaharuan dalam Sistem Hukum Pidana Indonesia", dalam Beberapa Guru Besar Berbicara tentang Hukum dan Pendidikan Hukum, Bandung: Binacipta, 1981, h. 64.

4 Muladi, Barda Nawawi Arief, Teori-teori dan Kebijakan Pidana, Bandung: Alumni, 1984, h. 84.

5 J.B.J.M. ten Berge dan N.M. Spelt, , Pengantar Hukum Perizinan, Surabaya: Yuridika, 1983, h. 2.
} 
pemerintah menggunakan izin sebagai sarana yuridis untuk mengemudikan tingkah laku para warga. ${ }^{6}$

Izin adalah Keputusan Tata Usaha Negara yang dikeluarkan oleh Badan/Pejabat Tata Usaha Negara yang digunakan oleh pemohon sebagai legitimasi terhadap kegiatan yang sebenarnya dilarang sebagai sarana bagi pemerintah untuk mengawasi kegiatan tertentu yang dilarang untuk menghalangi keadaan-keadaan yang buruk. ${ }^{7}$ Hal ini berbeda dengan pengertian dispensasi yang merupakan perkecualian atas larangan sebagai aturan umum yang pemberiannya berkaitan erat dengan keadaan-keadaan khusus. ${ }^{8}$ Berdasarkan pengertian izin, maka tujuan izin adalah sebagai instrumen dalam mengendalikan aktivitas masyarakat dengan cara mempengaruhi para warga agar mau mengikuti cara-cara yang dianjurkan guna mencapai suatu tujuan. ${ }^{9}$ Sesuai dengan banyaknya jenis perizinan yang dikeluarkan oleh pemerintah, maka selain mengendalikan aktivitas masyarakat masing-masing izin mempunyai fungsi atau motif berupa: 1)Keinginan mengarahkan aktivitas-aktivitas tertentu, misalnya izin bangunan; 2) Mencegah bahaya lingkungan, misalnya izin-izin lingkungan; 3) Keinginan melindungi objek-objek tertentu, misalnya izin penebangan; 4) Hendak membagi benda-benda yang sedikit, misalnya izin penghunian; 5) Pengarahan dengan menyeleksi orang-orang dan/atau aktivitas-aktivitas, dimana pengurus harus memenuhi syarat-syarat tertentu, misalnya Surat Izin Mengemudi. ${ }^{10}$

Pada umumnya sistem izin terdiri atas larangan, persetujuan yang merupakan dasar perkecualian dan ketentuan-ketentuan yang berhubungan dengan izin. Sistem perizinan memiliki tiga bagian pokok yang disebut aspek yuridis sistem perizinan, yaitu: Larangan, Izin dan Ketentuan-ketentuan. Larangan merupakan dasar penetapan persetujuan atau izin yang ditetapkan oleh pemerintah sebagai instrumen yuridis yang bersifat pencegahan atau berkarakter sebagai preventif instrumental. ${ }^{11}$ Izin merupakan instrumen yang biasa dipakai dalam hukum administrasi, yang dimaksudkan untuk mempengaruhi para warganya agar supaya mau mengikuti cara yang dianjurkan guna mencapai tujuan yang konkrit. Dengan demikian azas yang melekat dalam hukum administrasi juga melandasi hukum perizinan, salah satu azas tersebut adalah azas negara hukum. ${ }^{12}$ Dengan dilandasi azas negara hukum, maka setiap

\footnotetext{
6 Ibid, h. 2

7 Keputusan Tata Usaha Negara sebagaimana ketentuan Pasal 1 angka 3 Undang Undang Nomor 5 tahun 1986 sebagaimana telah diubah dengan Undang Undang Nomor 10 Tahun 2004 tentang Peradilan tata Usaha Negara adalah penetapan tertulis yang dikeluarkan oleh badan/pejabat tata usaha negara yang berisi tindakan hukum tata usaha negara, yang bersifat konkret, individual, final, serta menimbulkan akibat hukum bagi seseorang atau badan hukum. Philipus Mandiri Hadjon, Pengantar Hukum Administrasi Indonesia, Yogyakarta : Gajah Mada University Press, 1995 (selanjutnya disingkat Philipus Mandiri Hadjon I), 1995, h. 138.

$8 \quad$ Ibid, h. 28.

9 J.B.J.M. ten Berge dan N.M. Spelt, Op.Cit., h. 5

10 Ibid, h. 4

11 Ibid, h. 126

12 Ide sentral dari negara hukum adalah pengakuan dan perlindungan terhadap hak-hak azasi manusia yang bertumpu atas prinsip kebebasan dan persamaan. Adanya undang-undang dasar akan memberikan jaminan konstitusional terhadap azas kebebasan dan persamaan. Adanya pembagian kekuasaan untuk menghindarkan penumpukan kekuasaan dalam satu tangan yang sangat cenderung kepada penyalahgunaan kekuasaan, berarti
} 
larangan yang menjadi dasar penetapan izin harus diatur dalam peraturan perundang-undangan, hal ini sebagai realisasi dari azas legalitas. ${ }^{13}$

Selain pelaksanaan azas negara hukum, dalam pelaksanaan tindakan pemerintah yang berupa penetapan izin juga harus merealisasi azas keabsahan yang meliputi: wewenang, substansi, dan prosedur, sehingga kewenangan pemerintah dalam menetapkan izin harus diatur dalam peraturan perundang-undangan. Pada dasarnya larangan dalam izin merupakan pembatasan terhadap hak seseorang, oleh karena itu setiap larangan harus ditetapkan dalam peraturan perundang-undangan yang mendapat persetujuan wakil rakyat.

Izin merupakan persetujuan dari pemerintah terhadap norma larangan, oleh karena itu izin harus ditetapkan dalam bentuk keputusan pemerintah bukan peraturan, karena izin berisi suatu norma penetapan bukan norma pengaturan. Sebagai pelaksanaan azas kepastian hukum, maka izin harus memuat uraian sejelas mungkin tentang isi izin yang diberikan. Isi izin ditetapkan dalam diktum, karena diktum merupakan inti dari keputusan yang berisi akibatakibat yang ditimbulkan dari keputusan. Izin merupakan salah satu bentuk dari Keputusan Tata Usaha Negara yang menciptakan hukum, ini berarti bahwa izin membentuk suatu hubungan hukum tertentu. Dalam hubungan hukum ini diciptakan oleh pemerintah hak-hak dan kewajibankewajiban tertentu bagi yang berhak.

Ketentuan-ketentuan adalah syarat-syarat yang menjadi dasar bagi pemerintah memberi izin. Fakta menunjukkan bahwa banyak izin yang dikaitkan pada syarat-syarat yang berhubungan erat dengan fungsi sistem perizinan sebagai salah satu instrumen pengendalian dari pemerintah. Ketentuan sebagai dasar pemberian izin dapat berupa: 1) Kewajibankewajiban yang dikaitkan pada izin dalam praktik hukum administrasi guna mencapai tujuan yang diinginkan; 2) Pembatasan-pembatasan dalam izin yang memberi kemungkinan untuk secara praktis membatasi tindakan yang diizinkan. Pembatasan dibentuk dengan menunjuk batas-batas dalam waktu, tempat atau dengan cara lain; 3) Dengan menetapkan syarat-syarat, akibat-akibat hukum tertentu digantungkan pada timbulnya suatu peristiwa di kemudian hari yang belum pasti.

Bank sebagai suatu badan usaha yang mempunyai kegiatan usaha menghimpun dana dari masyarakat dan menyalurkannya kembali kepada masyarakat dalam berbagai bentuknya, sudah tentu membutuhkan persyaratan dalam melaksanakan kegiatan usahanya. Ini sangat penting untuk melindungi kepentingan masyarakat, terutama terhadap nasabah penyimpan dan

pemerkosaan terhadap kebebasan dan persamaan. Philipus Mandiri Hadjon, Perlindungan Hukum Bagi Rakyat, Surabaya : PT Bina Ilmu, 1987 (selanjutnya disingkat Philipus Mandiri Hadjon II), h. 76.

13 Azas legalitas adalah azas yang menentukan bahwa tiap-tiap perbuatan pidana harus ditentukan dalam undang-undang, bahkan tidak dipidana jika tidak ada kesalahan. Makanya harus menghindar dari kesalahan kecuali overmacht. Tidak boleh dihukum barang siapa melakukan perbuatan karena terdorong oleh berat lawan. Yang menjadi persoalan sekarang ialah, apakah daya paksa yaitu daya yang memaksa itu merupakan paksaan pisik, terhadap mana orang yang terkena dapat menghindarkan diri, atau merupakan paksaan psychis, dalam batin, terhadap mana meskipun secara pisik orang masih dapat menghindarkannya, namun daya itu adalah demikian besarnya. Moeljatno, Azas-azas Hukum Pidana, Jakarta: Rineksa Cipta, 1993 (selanjutnya disingkat Moeljatno II), h. 139 . 
simpanannya. Undang Undang Nomor 7 Tahun 1992 sebagaimana telah diubah dengan Undang Undang Nomor 10 Tahun 1998 tentang Perbankan (UU Perbankan) mengatur mengenai perizinan untuk menjalankan kegiatan usaha dalam ketentuan Pasal 16 ayat (1), (2), (3). Dalam ketentuan Pasal 16 ayat (1) UU Perbankan terkandung arti bahwa kegiatan menghimpun dana dari masyarakat oleh siapa pun pada dasarnya merupakan kegiatan yang perlu diawasi, mengingat dalam kegiatan itu terkait kepentingan masyarakat yang dananya disimpan pada pihak yang menghimpun dana tersebut.

Sehubungan dengan itu dalam Pasal 16 ayat (1) ditegaskan bahwa kegiatan menghimpun dana dari masyarakat dalam bentuk simpanan hanya dapat dilakukan oleh pihak yang telah memperoleh izin usaha sebagai Bank Umum atau sebagai Bank Perkreditan Rakyat, atau bentuk lain dari lembaga bank yang melakukan kegiatan menghimpun dana dari masyarakat, yaitu Perbankan Syariah baik Bank Syariah, Unit Pembiayaan Rakyat Syariah atau Unit Usaha Syariah sebagaimana yang telah diatur dalam Undang Undang Nomor 21 Tahun 2008 tentang Perbankan Syariah (UU No. 21/2008).

Terdapat pula jenis lembaga lainnya yang juga melakukan kegiatan menghimpun dana dari masyarakat dalam bentuk simpanan atau semacam simpanan, misalnya yang dilakukan oleh kantor pos, oleh dana pensiun, atau oleh perusahaan asuransi. Kegiatan lembaga-lembaga tersebut tidak dicakup sebagai kegiatan usaha perbankan berdasarkan ketentuan Pasal 16 ayat (1) UU Perbankan, namun diatur dengan undang-undang tersendiri.Dari ketentuan Pasal 16 ayat (2) dapat dikemukakan bahwa dalam hal memberikan izin usaha sebagai Bank Umum dan Bank Perkreditan Rakyat, Bank Indonesia selain memperhatikan pemenuhan persyaratan sebagaimana dimaksud dalam ayat ini, juga wajib memperhatikan tingkat persaingan yang sehat antar bank, tingkat kejenuhan jumlah bank dalam suatu wilayah tertentu, serta pemerataan pembangunan ekonomi nasional. ${ }^{14}$

Berdasarkan ketentuan Pasal 16 ayat (1), dan ayat (2), maka berhubungan dengan ketentuan Pasal 16 ayat (3) UU Perbankan dapat dikemukakan bahwa pokok-pokok ketentuan yang ditetapkan oleh Bank Indonesia memuat antara lain adalah: 1)persyaratan untuk menjadi pengurus bank antara lain menyangkut keahlian di bidang perbankan dan konduite yang baik; 2) larangan adanya hubungan keluarga di antara pengurus bank; 3) modal disetor minimum untuk pendirian Bank Umum dan Bank Perkreditan Rakyat; 4) batas maksimum kepemilikan dan kepengurusan; 5) kelayakan rencana kerja; 6) batas waktu pemberian izin pendirian bank. ${ }^{15}$

Undang-Undang Perbankan membedakan secara tegas bentuk hukum untuk Bank Umum, bentuk hukum untuk Bank Perkreditan Rakyat, bentuk hukum untuk Bank Syariah, dan bentuk hukum dari kantor perwakilan dan kantor cabang yang berkedudukan di luar negeri.Dalam Pasal 21 ayat (1) UU Perbankan, Bank Umum memiliki tiga bentuk hukum, yaitu perseroan terbatas, koperasi, dan perusahaan daerah, untuk Bank Perkreditan Rakyat yang

14 Hermansyah, Hukum Perbankan Nasional Indonesia,Jakarta : Kencana Prenada Media Group, 2007, h. 26.

15 Ibid. 
diatur dalam Pasal 21 ayat (2) bentuk hukumnya adalah perusahaan daerah, koperasi, perseroan terbatas, dan bentuk lain yang ditetapkan dengan peraturan pemerintah.

Sedangkan bentuk hukum dari Bank Syariah adalah perseroan terbatas sebagaimana ketentuan Pasal 2 Peraturan Bank Indonesia Nomor 11/3/PBI/2009 tentang Perbankan Syariah. Dan bentuk hukum dari kantor perwakilan dan kantor cabang yang berkedudukan di luar negeri adalah mengikuti bentuk hukum kantor pusatnya sebagaimana ditentukan dalam Pasal 21 ayat (3) UU Perbankan.

Ketentuan Pasal 22 ayat (1) UU Perbankan menyatakan bahwa Bank Umum hanya dapat didirikan oleh warga negara Indonesia dan/atau badan hukum Indonesia, warga negara Indonesia dan/atau badan hukum Indonesia dengan warga negara asing dan/atau badan hukum asing secara kemitraan. Kemudian Pasal 22 ayat (2) menentukan bahwa ketentuan mengenai persyaratan pendirian bank yang wajib dipenuhi sebagaimana dimaksud dalam Pasal 22 ayat (1) ditetapkan oleh Bank Indonesia.

Ketentuan mengenai pendirian Bank Umum di atas, tidak berlaku bagi pendirian Bank Perkreditan Rakyat. Untuk pendirian Bank Perkreditan Rakyat berlaku ketentuan sendiri yang sedikit berbeda dengan pendirian Bank Umum. Menurut Pasal 23 UU Perbankan, Bank Perkreditan Rakyat hanya dapat didirikan dan dimiliki oleh warga negara Indonesia, badan hukum Indonesia yang seluruh pemiliknya warga negara Indonesia, pemerintah daerah, atau dapat memiliki bersama ketiganya.

Berbeda lagi ketentuan mengenai pendirian Bank Syariah, ketentuan pendirian bank syariah dalam Pasal 16 ayat (1) Peraturan Bank Indonesia Nomor 11/3/PBI/2009 menyatakan bahwa selain dapat didirikan oleh warga negara Indonesia dan/atau badan hukum Indonesia; warga negara Indonesia dan/atau badan hukum Indonesia dengan warga negara asing dan/atau badan hukum asing secara kemitraan, Bank Syariah dapat dimiliki oleh pemerintah daerah. Selanjutnya dalam ketentuan Pasal 16 ayat (2) Peraturan Bank Indonesia Nomor 11/3/PBI/2009 tertera ketentuan kepemilikan oleh warga negara asing dan/atau badan hukum asing sebagaimana dimaksud pada ayat (1) huruf b paling banyak sebesar 99\% dari modal disetor Bank.

\section{Kriminalisasi Perizinan}

Masyarakat, ilmu pengetahuan dan teknologi terus berkembang dan membawa konsekuensi terhadap beberapa hal yang diatur dalam KitabUndang-UndangHukumPidana yang dalam perjalanan selanjutnya perlu disesuaikan, karena sudah tidak sejalan dengan perkembangan dimaksud. Terlebih lagi, telah ada perubahan nilai-nilai dan sikap-sikap warga masyarakat yang disebut sistem hukum, yaitu struktur hukum, kultur hukum, dan substansi hukum. Perubahan nilai tersebut menyebabkan sejumlah perbuatan yang tadinya tidak tercela dan tidak dituntut pidana menjadi perbuatan tercela dan perlu dipidana. ${ }^{16}$

Pendapat-pendapat di atas memberikan refleksi keadaan hukum pidana di negeri

16 Wolfgang Friedman, Filsafat Hukum, dikutip dalam Hamzah Hatrik, Op.Cit., h. 3. 
kita yang sangat memerlukan pembaharuan dengan persoalan kriminalisasi sebagai wujud dinamika hukum pidana dalam konteks perubahan-perubahan yang terjadi di masyarakat. Karena itu kebijakan penanggulangan kejahatan dengan hukum pidana perlu dilakukan dengan cara pendekatan integral antara kebijakan penal dan nonpenal. ${ }^{17}$ Pendekatan integral antara kebijakan penal dan nonpenal memberikan pengertian bahwa usaha-usaha yang rasional dalam penanggulangan kejahatan tidak hanya menggunakan sarana hukum pidana, tetapi dapat pula dilakukan melalui usaha non hukum pidana, misalnya meningkatkan fungsi perizinan dalam setiap pendirian usaha bank dan dalam setiap mengeluarkan produk perbankan. Melalui mengintensifkan dan mengefektifkan sarana nonpenal diharapkan penanggulangan kejahatan bisa lebih optimal.

Pelanggaran-pelanggaran terhadap ketentuan perizinan sebagaimana dimaksud melahirkan sebuah penegakan hukum dari sudut hukum pidana administrasi (Administrative penal law). Penegakan hukum dimaksud merupakan suatu terobosan hukum yang dibuat oleh pembuat undang-undang untuk mengatasi pelanggaran-pelanggaran dalam hal tidak dipenuhinya ketentuan perizinan yang diharuskan undang-undang. Namun penegakan hukum pidana administrasi dalam Undang Undang Perbankan telah beralih menjadi penegakan hukum pidana murni dimana sanksi pidana yang dikenakan tidak lagi bersifat ultimum remedium, akan tetapi sifatnya berubah menjadi primum remedium.

Rumusan Pasal 46 UU Perbankan dengan jelas menyebutkan bahwa kegiatan menghimpun dana tanpa izin dari Pimpinan Bank Indonesia adalah ilegal (tanpa hak dan melawan hukum). Selanjutnya pertanggungjawaban korporasi untuk kegiatan sebagaimana dimaksud, selain dipidananya pelaku tindak pidana dapat dikenakan pidana tambahan berupa pencabutan izin sebagaimana diatur dalam Pasal 16 UU Perbankan.

Mekanisme pengenaan sanksi yang diberikan oleh UU Perbankan terhadap pelanggar ketentuan perizinan bank tersebut menunjukkan peran penting sarana penal dalam penegakan ketentuan perizinan pendirian bank, baik secara langsung sebagai sarana represif atau secara tidak langsung untuk dimaksudkan sebagai sarana preventif. Hal ini merupakan konsekuensi atas diterapkannya penalisasi dalam lingkup perizinan yaitu perubahan sanksi administrasi menjadi sanksi pidana karena sanksi administrasi tersebut melanggar kepentingan umum. Moeljatno mengatakan bahwa yang dimaksud dengan hukum pidana adalah bagian daripada keseluruhan hukum yang berlaku di suatu negara, yang mengadakan dasar-dasar dan aturan untuk : (1) menentukan perbuatan-perbuatan mana yang boleh dilakukan, yang dilarang, dengan disertai ancaman, atau sanksi berupa pidana tertentu bagi barang siapa yang melanggar larangan tersebut, (2) menentukan kapan dan dalam hal-hal apa kepada mereka yang telah melanggar larangan-larangan itu dapat dikenakan atau dijatuhi pidana sebagaimana telah diancamkan, dan (3) menentukan dengan cara bagaimana pengenaan pidana itu dapat dilaksanakan apabila ada orang yang disangka telah melanggar larangan tersebut. ${ }^{18}$

17 Muladi dan Barda Nawawi Arief, Op.Cit, h. 158-160.

18 Moeljatno I, Op.Cit., h. 1. 
Sedangkan mengenai pengertian tindak pidana, Moeljatno mengartikannya sebagai perbuatan yang dilarang oleh suatu aturan hukum, larangan mana disertai ancaman yang berupa pidana tertentu, bagi barang siapa yang melanggar larangan tersebut. ${ }^{19}$ Sehingga dapat dikatakan bahwa tindak pidana adalah perbuatan yang oleh suatu aturan hukum dilarang dan diancam pidana, asal saja dalam pada itu diingat bahwa larangan ditujukan pada perbuatan, yaitu suatu keadaan atau kejadian yang ditimbulkan oleh kelakuan orang, sedangkan ancaman pidananya ditujukan kepada orang yang menimbulkan kejadian itu. ${ }^{20}$

Secara umum bentuk tindak pidana dibagi menjadi dua jenis, yaitu kejahatan dan pelanggaran. Kejahatan adalah sebagian dari perbuatan-perbuatan yang dilarang dan diancam dengan pidana, barang siapa melakukannya. Pada dasarnya kejahatan diatur dalam Buku Kedua Kitab Undang Undang Hukum Pidana (KUHP). Selain itu, ada pula kejahatan yang diatur di luar KUHP.Perbuatan-perbuatan yang dilarang dan diancam dengan pidana bagi barang siapa yang melakukannya bukan semata-mata kejahatan, tetapi meliputi juga pelanggaran. Pelanggaran ini pada pokoknya diatur dengan Buku Ketiga KUHP dan undang-undang lain yang menyebutkan secara tegas suatu perbuatan sebagai pelanggaran.

Berkaitan dengan itu, dalam UU Perbankan telah menyatakan secara tegas mengenai perbuatan apa yang dilarang, baik sebagai bentuk kejahatan maupun pelanggaran.Dikategorikan sebagai tindak pidana kejahatan dibidang perbankan menurut UU Perbankan adalah sebagaimana disebut dalam ketentuan Pasal 51 ayat (1) UU Perbankan.

Berkaitan dengan itu, dalam penjelasan dikemukakan bahwa perbuatan-perbuatan sebagaimana dimaksud dalam pasal-pasal tersebut dalam ayat ini digolongkan sebagai tindak pidana kejahatan, bahwa terhadap perbuatan-perbuatan dimaksud akan dikenakan ancaman hukuman yang lebih berat dibandingkan dengan apabila sekedar sebagai pelanggaran. Mengingat bahwa bank adalah lembaga yang menyimpan dana yang dipercayakan mayarakat kepadanya, yang pada dasarnya juga akan merugikan bank maupun masyarakat dengan dilakukannya tindak pidana tersebut.

Ketentuan Pasal 46 ayat (1) UU Perbankan memberikan ketentuan pidana bagi pelanggaran terhadap kewajiban mempunyai izin usaha bagi setiap kegiatan mengimpun dana dari masyarakat. Selanjutnya dalam Pasal 46 ayat (2), bagi pelanggar kewajiban memiliki izin usaha bank berupa korporasi penuntutan dialihkan pada mereka yang memberi perintah melakukan perbuatan itu atau yang bertindak sebagai pimpinan terhadap perbuatan itu atau terhadap kedua-duanya.

\section{Penyalahgunaan Perizinan Dalam Bank Umum}

Landasan yuridis pertanggungjawaban pelaku dalam tindak pidana perbankan di bidang perizinan tunduk pada pengaturan Pasal 16 dan Pasal 46 UU Perbankan. Pasal 16 menyebutkan bahwa setiap kegiatan menghimpun dana dari masyarakat harus mendapatkan izin dari

19 Ibid, h. 47 .

20 Ibid. 
Pimpinan Bank Indonesia melalui syarat dan ketentuan yang harus dipenuhi sebagaimana telah ditetapkan oleh Bank Indonesia. Juga melalui tiap-tiap aturan yang tersendiri untuk tiap-tiap jenis bank salah satunya Peraturan Bank Indonesia Nomor 11/1/PBI/2009 untuk Bank Umum.

Untuk mengetahui perbuatan apa yang dilarang sebagai bentuk tindak pidana perbankan di bidang perizinan diperlukan pemahaman mengenai unsure delik dalam Pasal 46 UU Perbankan sebagai satu-satunya aturan pokok yang memuat larangan pendirian usaha bank tanpa izin yang sah beserta ketentuan pidananya dalam peraturan perundang-undangan di bidang perbankan di Indonesia. Berdasarkan ketentuan yang telah disebutkan di atas unsur delik perbuatan pelanggaran kewajiban izin usaha bank adalah sebagai berikut : a) Dilakukan oleh setiap pihak, baik perseorangan maupun korporasi; b) Kegiatan yang dilakukan adalah menghimpun dana dari masyarakat; c) Dihimpun dalam bentuk simpanan (sesuai jenis bank); d) Kegiatan menghimpun dana tersebut tanpa izin usaha yang sah dari Pimpinan Bank Indonesia.

Unsur yang pertama adalah bahwa perbuatan tersebut dilakukan oleh setiap pihak, baik perseorangan maupun korporasi. Pembahasan mengenai subjek hukum korporasi akan dilakukan lebih rinci pada bab selanjutnya. Sedangkan unsur lembaga perbankan adalah lembaga keuangan yang menjadi perantara antara pihak yang mempunyai kelebihan dana (surplus of funds) dengan pihak yang membutuhkan dana (lacks of funds), tentu membutuhkan dana yang tidak sedikit dalam menjalankan kegiatan usaha atau operasionalnya.

Pada hakikatnya lembaga keuangan adalah semua badan yang melalui kegiatankegiatannya di bidang keuangan menarik uang dari dan menyalurkannya ke dalam masyarakat. Sebagai lembaga keuangan bank mempunyai kegiatan pokok berupa menghimpun dana dari masyarakat untuk disalurkan kembali kepada masyarakat yang membutuhkan dana dalam bentuk kredit atau pembiayaan berdasarkan prinsip syariah. Fungsi untuk mencari dan menghimpun dana dari masyarakat memegang peranan penting terhadap suatu bank, sebab volume dana yang berhasil dihimpun atau disimpan tentunya akan menentukan pula volume dana yang dapat dikembangkan oleh bank tersebut dalam bentuk penanaman dana yang menghasilkan, misalnya dalam bentuk pemberian kredit, pembelian efek-efek, atau surat-surat berharga di pasar uang.

Dengan perkataan lain dana yang dibutukan dalam pengelolaan bank tidak semata-mata hanya mengandalkan modal yang dimiliki oleh bank saja, tetapi harus sedemikian rupa dapat memobilisasi dan memotivasi masyarakat untuk menyimpan dana yang dimilikinya di bank, baik berupa simpanan maupun dalam bentuk lain, dan melalui kerja sama dengan lembaga-lembaga keuangan. Unsur yang ke tiga adalah dana yang dihimpun dari masyarakatdirupakan ke dalam bentuk simpanan. Dana yang berasal dari masyarakat tersebut pada prinsipnya merupakan dana yang harus diolah atau dikelola oleh bank dengan sebaik-baiknya agar memperoleh keuntungan. Sedangkan yang dimaksud dengan simpanan dari masyarakat adalah dana yang dipercayakan oleh masyarakat kepada bank berdasarkan perjanjian pemyimpanan dana. Menghimpun dana dari masyarakat sebagaimana disebutkan dalam Pasal 6 UU Perbankan diwujudkan dalam bentuk : giro, deposito berjangka, sertifikat deposito, dan tabungan. 
Secara umum giro adalah simpanan pihak ke tiga pada bank yang penarikannya dapat dilakukan setiap saat dengan mempergunakan cek, surat perintah pembayaran lainnya, atau dengan cara pemindahbukuan. Pengertian giro yang dimuat dalam Pasal 1 butir 6 UU Perbankan bahwa giro adalah simpanan yang penarikannya dapat dilakukan setiap saat dengan menggunakan cek, bilyet giro, saran perintah pembayaran lainnya atau dengan pemindahbukuan. Sedangkan ketentuan mengani cek datur dalam Kitab Undang Undang Hukum Dagang.

Pengertian deposito dimuat dalam Pasal 1 butir 7 UU Perbankan adalah simpanan yang penarikannya hanya dilakukan pada waktu tertentu berdasarkan perjanjian nasabah penyimpan dana dengan bank. Apabila simpanan deposito mengandung jangka waktu tiga bulan maka uang tersebut baru dapat dicairkan setelah jangka waktu tersebut berakhir. Sebagai contoh jika seorang deposan mendepositokan uang tanggal 30 September 2009 untuk tiga bulan mendatang maka tanggal jatuh temponya yaitu tanggal 30 Desember 2009.

Untuk mencairkan deposito yang dimiliki deposan dapat menggunakan sertifikat deposito, deposito on call, dan deposito automatic rolled over. Sertifikat deposito adalah deposito berjangka yang bukti penyimpanannya dapat dipindahtangankan, sebagaimana diatur dalam pasal 1 butir 8 UU Perbankan. Sedangkan deposito on call berarti deposito yang pengambilannya berdasarkan pemberitahuan terlebih dahulu, sesuai dengan perjanjian nasabah penyimpan dana dengan bank. Kemudianbentuk yang terakhiryakniautomatic rolled overdenganpengertiandeposito yang terusberjalanatauperpanjanganotomatis.

\section{Penyalahgunaan Perizinan dalam Bank Perkreditan Rakyat}

Ketentuan larangan melakukan kegiatan usaha menghimpun dana dari masyarakat dalam lingkup Bank Perkreditan Rakyat tidak memiliki perbedaan prinsipiil terhadap pengaturan perizinan melakukan usaha sebagai Bank Umum. Selain tunduk pada ketentuan Pasal 16 dan Pasal 46 UU Perbankan kegiatan menghimpun dana dalam lingkup usaha Bank Perkreditan Rakyat juga tunduk pada ketentuan Peraturan Bank Indonesia Nomor 8/26/PBI/2006. Hanya saja produk perbankan yang dikeluarkan sebagai sarana penghimpun dana dari masyarakatoleh Bank Perkreditan Rakyat berbeda dengan produk perbankan yang dikeluarkanoleh Bank Umum. dalam hal ini Pasal 13 UU Perbankan memberikan ketentuan bahwa Bank Perkreditan Rakyat melakukan usaha menghimpun dana dari masyarakat hanya dalam bentuk simpanan berupa deposito berjangka dan tabungan.

\section{Penyalahgunaan Perizinan dalam Bank Syariah}

Perkembangan Perbankan Syariah dimulai pada dekade 1960 di Timur Tengah. Namun aktivitas lembaga keuangan dengan prinsip dasar syariah telah dilaksanakan sejak awal perkembangan Islam di dunia, dibuktikan dengan adanya transaksi-transaksi berupa pemberian pinjaman, penyimpanan uang (deposito), dan tukar-menukar uang (money changer) yang 
semuanya merupakan bentuk dari transaksi modern saat ini. ${ }^{21}$ Di Indonesia, perkembangan perbankan syariah mulai giat pada lebih dari 10 tahun terakhir. Perkembangan yang sangat baik dari sisi pembiayaan yang diberikan, penghimpunan dana, kinerja serta pengembangan infra struktur perbankan syariah secara nasional. Hal tersebut tidak dapat dilepaskan dari peran pemerintah khususnya perhatian terhadap UU No. 21/2008 di Indonesia. ${ }^{22}$

Perbankan Syariah dalam melakukan kegiatan penghimpunan dan menerima dana dari masyarakat dalam tiga jenis simpanan dan juga berupa pinjaman dari lembaga keuangan yang kegiatan operasionalnya berdasarkan syariah, yaitu: 1) Giro yang sesuai dengan prinsip al_ wadiah $^{23}$. Giro berdasarkan prinsip al-wadiah dimaksudkan bank dapat menggunakan dana yang berasal dari giro dengan atau tanpa izin dari nasabah untuk membiayai kegiatan operasi bank; 2) Tabungan dalam perbankan syariah menggunakan prinsip yang sama seperti yang dijalankan oleh perbankan konvensional, atau dapat pula menggunakan prinsip al wadiah dan al-mudharabah" ; 3 ) Deposito berjangka yang sesuai dengan prinsip al mudharabah, yaitu para deposan diberikan imbalan atas dasar pembagian keuntungan begitu juga apabila terjadi kerugian.

Dalam masyarakat sering juga kita temui kegiatan menghimpun dana yang dilakukan oleh perorangan atas nama orang itu sendiri tanpa melibatkan suatu instansi lembaga perbankan atau lembaga lain yang dalam anggaran dasar pendiriannya memang mencantumkan kegiatan menghimpun dana dari masyarakat (berdasarkan ketentuan dalam undang-undang yang mengatur masing-masing lembaga penghinpun dana non bank) sebagai salah satu bentuk usaha yang dilakukan.

Dengan pembatasan apabila kegiatan menghimpun dana dilakukan dalam bentuk simpanan sebagaimana dimaksud dalam Pasal 46 UU Perbankan maka kegiatan menghimpun dana tersebut tunduk pada Undang Undang Perbankan. Sedangkan apabila dana yang dihimpun melalui kegiatan penghimpunan dana di luar pengaturan UU Perbankan dihimpun melalui instrumen yang juga diatur di luar UU Perbankan, maka ketentuan pengaturan tunduk kepada peraturan sebagaimana dimaksud.

\section{Kesimpulan}

Landasan yuridis pertanggungjawaban korporasi dalam tindak pidana perizinan di bidang perbankan diatur dalam Pasal 46 ayat (1) dan ayat (2) UU Perbankan. Mengenai

${ }^{21}$ Asariwarni, Penerapan Prinsip Syariah Pada Perbankan Konvensional, Majalah Hukum Nasional Nomor 2, Badan Pembinaan Hukum Nasional Departemen Hukum dan HAM RI. 2005, h. 131-142.

22 Ibid,h. 131.

23 Prinsip al wadiah adalah prinsip yang menggariskan bahwa perjanjian antara pemilik barang dengan penyimpan dimana pihak penyimpanan bersedia untuk menyimpan dan menjaga keselamatan barang yang dititipkan kepadanya. Ibid, h. 132.

24 Mudharabah merupakan hubungan berkaitan antara dua pihak yaitu pemilik dana atau harta dan pihak yang memiliki keahlian atau pengalaman. Dalam perjajian ini pemilik modal bersedia membiayai sepenuhnya usaha dan pengusaha setuju untuk mengelola poyek tersebut dengan pembagian hasil sesuai dengan perjanjian. Pemilik modal tidak dibenarkan ikut dalam pengelolaan usaha, tapi diperbolehkan membuat usulan dan melakukan pengawasan. Ibid, h.133. 
pengaturan perizinan Bank Umum, Bank Perkreditan Rakyat dan Bank Syariah diatur dalam peraturan tersendiri, Peraturan Bank Indonesia Nomor 11/1/PBI/2009 tentang Bank Umum, Peraturan Bank Indonesia Nomor 8/26/PBI/2006 tentang Bank Perkreditan Rakyat, Peraturan Bank Indonesia Nomor 13/3/PBI/2009 tentang Bank Umum Syariah. Mekanisme pengenaan sanksi yang diberikan oleh UU Perbankan terhadap pelanggar ketentuan perizinan bank tersebut menunjukkan peran penting sarana penal dalam penegakan ketentuan perizinan pendirian bank, baik secara langsung sebagai sarana represif atau secara tidak langsung untuk dimaksudkan sebagai sarana preventif. Hal ini merupakan konsekuensi atas diterapkannya penalisasi dalam lingkup perizinan yaitu perubahan sanksi administrasi menjadi sanksi pidana karena sanksi administrasi tersebut melanggar kepentingan umum.

\section{Daftar Bacaan}

Buku

Hadjon, Philipus Mandiri, Pengantar Hukum Administrasi Indonesia, Yogyakarta:Gajah Mada University Press, 1995.

---------, PerlindunganHukumBagi Rakyat, Bina Ilmu, 1987.

Hermansyah, Hukum Perbankan Nasional Indonesia,Jakarta:Kencana Prenada Media Group, 2007.

Moeljatno, Azas-azasHukumPidana, Jakarta:RinekaCipta, 1993.

Muladi, Barda Nawawi Arief, Teori-teori dan Kebijakan Pidana, Bandung:Alumni, 1984.

Kusumaatmadja,Mochtar. Masyarakat dan Pembinaan Hukum Nasional Suatu Uraian tentang Landasan Pikiran, Pola dan Mekanisme Pembaharuan Hukum di Indonesia. Bandung:Binacipta, 1976.

Rahardjo,Satjipto,Hukum, Masyarakat dan Pembangunan, Bandung:Alumni, 1980.

\section{Makalah}

Asariwarni, "Penerapan Prinsip Syariah Pada Perbankan Konvensional".Majalah Hukum Nasional Nomor 2, Badan Pembinaan Hukum Nasional Departemen Hukum dan HAM RI. 2005.

Berge, J.B.J.M. Ten dan N.M. Spelt, “Pengantar Hukum Perizinan”, Cetakan Pertama, Yuridika, $1983,$. 